University of Wollongong

Research Online

Faculty of Law, Humanities and the Arts Papers (Archive)

Faculty of Arts, Social Sciences \& Humanities

2000

Pro-activity, partnership and prevention: the UK contribution to policing organised crime in Europe

Clive Harfield

University of Wollongong, clive@uow.edu.au

Follow this and additional works at: https://ro.uow.edu.au/lhapapers

Part of the Arts and Humanities Commons, and the Law Commons

Research Online is the open access institutional repository for the University of Wollongong. For further information contact the UOW Library: research-pubs@uow.edu.au 


\title{
Pro-activity, partnership and prevention: the UK contribution to policing organised crime in Europe
}

\author{
Abstract \\ Whatever the outcome of political initiatives within the European Union (EU) and other European states \\ regarding closer integration of political and economic institutions, there has long been evident an \\ increasing integration and cooperation amongst the higher echelon of criminals across the continent. 1 \\ Whether or not the EU expands its membership, refines its constitution, harmonises the laws of Member \\ States or even disintegrates, law enforcement agencies across Europe will continue to have to deal with \\ the significant threat posed to national and global infrastructures by the free market of organised crime \\ (Fiorentini \& Peltzman, 1995; see also Williams, 1998: 265-8). This market will feed off opportunities \\ presented by the EU but will also flourish in the absence of such a supranational entity. This paper \\ considers approaches that are being adopted within the UK to the policing needs of Europe and possible \\ responses to new demands with particular reference to organised crime.

\section{Keywords} \\ contribution, prevention, policing, crime, europe, uk, partnership, organised, activity, pro

\section{Disciplines} \\ Arts and Humanities | Law

\section{Publication Details} \\ C. Harfield, 'Pro-activity, partnership and prevention: the UK contribution to policing organised crime in \\ Europe' (2000) 73 (2) The Police Journal 107-117.
}


CLIVE HARFIELD

Detective Inspector, National Crime Squad

\section{PRO-ACTIVITY, PARTNERSHIP AND PREVENTION:}

\section{THE UK CONTRIBUTION TO POLICING ORGANISED CRIME IN EUROPE}

Whatever the outcome of political initiatives within the European Union (EU) and other European states regarding closer integration of political and economic institutions, there has long been evident an increasing integration and cooperation amongst the higher echelon of criminals across the continent. ${ }^{1}$ Whether or not the EU expands its membership, refines its constitution, harmonises the laws of Member States or even disintegrates, law enforcement agencies across Europe will continue to have to deal with the significant threat posed to national and global infrastructures by the free market of organised crime (Fiorentini \& Peltzman, 1995; see also Williams, 1998: 265-8). This market will feed off opportunities presented by the EU but will also flourish in the absence of such a supranational entity. This paper considers approaches that are being adopted within the UK to the policing needs of Europe and possible responses to new demands with particular reference to organised crime.

\section{The Need for a UK Police Response}

There are two drivers within the European context demanding a response from UK police forces. The first is not new, but is gaining in its significance. As long ago as the late 1960s Kent County Constabulary recognised their need to address the localised transnational criminality that focused on cross-Channel communications, and established the force European Liaison Unit (ELU) to handle transnational enquiries (Gallagher, 1998). ${ }^{2}$ Other forces have since established similar specialist units, for instance, Hampshire Constabulary's International Liaison and Enquiry Team. Entirely within the remit of local UK forces, although to some extent dependent upon geographical proximity to Europe, there is an increasing need to be able to secure evidence located abroad that relates to criminal investigations otherwise focused within a single UK force area.

If this first is a bottom-up driver for police cooperation in reactive investigations, then the second driver is assuredly top-down and proactive. Title VI of the Treaty of Amsterdam (TA) announces 'Provisions on Police and Judicial Cooperation in Criminal Matters'. It lays the 
foundation for transferring some aspects of policing from the intergovernmental cooperation sphere of the 'Third Pillar' to the EU institutional framework of the 'First Pillar':

... the Union's objective shall be to provide citizens with a high level of safety within an area of freedom, security and justice by developing common action among the Member States in the fields of police and judicial cooperation in criminal matters and by preventing and combating racism and xenophobia. (Article 29, TA)

Europol, previously an organisation set apart from the EU, is now incorporated as the mechanism by which cooperation is to be enhanced and even directed (TA, Article 30(2)). The Presidency Conclusions of the Tampere European Council ${ }^{3}$ reinforce the impetus of the TA by calling for the "joint mobilisation of police and judicial resources . . . to guarantee that there is no hiding place for criminals or the proceeds of crime within the Union' (Presidency Conclusions, para. 6). Of particular concern to the EU is trafficking (in whatever commodity) and financial fraud (see also Knudsen, 1998). Having taken 40 years to establish a sophisticated, supranational economic infrastructure, the EU is understandably concerned to protect it from levels of organised criminality that cannot have been foreseen when the Treaty of Rome was signed in 1957. The Presidency Conclusions call for efforts to detect and dismantle criminal networks (para. 23), for action to prevent organised crime at EU level (paras 41 and 42) and for a European Police Chiefs Operational Taskforce 'to exchange, in cooperation with Europol, experience, best practices and information on current trends in cross-border crime and contribute to the planning of operative actions' (para. 44). This level of response is largely beyond the remit of local UK forces. The clear indication is that, through Europol, the EU will seek UK cooperation in tackling aspects of organised crime that are impacting on the EU.

In this respect of course, such criminality also impacts on the UK as an EU Member State. It is inconceivable that criminals in a position to exploit large-scale and profit-focused criminal opportunities across the EU are not already honing their skills with criminal enterprises conducted within individual Member States. There is considerable selfinterest for the UK in cooperating with the EU's new initiatives against organised crime. ${ }^{4}$ For law enforcement agencies in the UK, 'partnership' and 'prevention' are messages now broadcast in stereo by the EU and the UK Government, and reinforced by the G8 countries (communiqué from the G8 Ministerial Conference on Combating Transnational Organised Crime, Moscow, 19-20 October 1999; see also Wrench, 1998).

\section{UK Structures for Dealing with European Policing Issues}

The National Criminal Intelligence Service (NCIS) provides a central point of communication for enquiries outbound from the UK and 
incoming from foreign authorities. Both Europol and Interpol liaison officers are collocated with NCIS. Although NCIS staff have no investigative or prosecution functions per se, they are in a position to facilitate enquiries and identify mutual intelligence interests. Investigations leading to prosecution remain the remit of enforcement agencies such as the police, immigration and customs, all of which deal with various forms of trafficking, and at least two of which potentially may investigate aspects of fraud as well.

The National Crime Squad of England and Wales has a remit to combat serious and organised, national and transnational crime that impacts on the UK (s. 48 of the Police Act 1997; Home Secretary's first objective, National Crime Squad Service Plan 1999/2000). Crossborder issues in Scotland, with its unique jurisdiction within the UK, are investigated by the Scottish Crime Squad. ${ }^{5}$ Each of these crime squads is in a position to tackle police investigations arising from the high-level organised criminality with which the EU is now concerned. Whether there are sufficient resources yet available will largely depend on how much work comes out of Europe via Europol, and to what extent the work already being carried out by the two squads is seen to be contributing to the EU initiatives.

At the level of transfrontier cooperation identified by Gallagher (1998), local UK forces will continue to take the lead in police matters as intervention at a national level would be inappropriate.

\section{Proactive Investigation}

It is difficult to treat as discrete entities proactivity, partnership and prevention issues since there is considerable overlap between them. The scale and sophistication of organised criminality is such that proactive, rather than reactive, investigation is the only effective means of detecting and disrupting such activity (Home Office, 1997: 7). Enforcement violence utilised by criminal gangs may well result in reactive murder investigations but such enquiries will address, within this context, only peripheral criminality, not the profit-motivated, largescale activity that threatens national infrastructures. Such reactive investigations fall within the remit of local UK forces at present, with linked series being jointly investigated by local forces as the series becomes apparent.

The UK must continue to maintain and develop mechanisms for the proactive investigation of on-going organised criminality. Such mechanisms include investigative organisations such as those referred to above and legislative instruments such as the Police Act 1997 (Part III) and the Regulation of Investigatory Powers Act 2000. For the organisations charged with such investigations, there is at issue their relationship with the locally based policing of 150 years' tradition. In the light of the threat posed, and the means available to deal with it, the role and remit of national investigative agencies may have to be reviewed in order better to address organised crime. Locally based policing, 
although it has a role in tackling organised crime as will be discussed below, is not structured to combat transnational and global-scale criminality. Indeed the principal legislative focus provided for UK policing (Policing Act 1996, Crime and Disorder Act 1998, Local Government Act 1999 and Scottish devolution) guides forces towards local, community issues rather than the wider criminal perspective. Not being in a position to combat transnational criminality, largely a phenomenon of the last quarter century, is not a viable option for any government.

\section{Partnership}

Partnership in the fight against organised crime exists at a number of levels and the key to successful partnership working is to avoid duplication. At the intergovernmental level the use of international treaties, supported by appropriate Signatory State domestic legislation, provides the strategic and political impetus. The mechanics of international mutual assistance within Europe are currently being updated and negotiated in the form of a draft EU Convention on Mutual Assistance in Criminal Matters (Nilsson, 1998). This treaty for EU Member States is intended to supplement the (now somewhat outdated) provisions of the 1959 European Convention on Mutual Assistance in Criminal Matters (European Treaty Series No. 30) and is open for ratification to all Council of Europe Member States.

These treaties govern cooperation both at the level of individual force enquiries and at the level of transnational organised crime investigations. Because such instruments are written with this breadth of provision, within these international treaty frameworks some enforcement authorities have found it useful at the tactical level to have interagency Memoranda of Understanding with their opposite numbers in foreign states. The ELU, for instance, now have three such Memoranda with various French and Dutch authorities and are seeking to enter into another with Belgian authorities. HM Customs and Excise have a large number of such memoranda with foreign customs agencies, mostly under the auspices of the 1988 UN Vienna Convention on Drugs (Harfield, 1999: 31).

At the operational level there is an increasing need for joint-agency operations in the field of transnational organised crime. This is true both between and within individual EU Member States. The draft convention envisages international joint investigation teams to which Europol will contribute intelligence and expertise. With the NCIS acting as the strategic level contact for Europol within the UK for such operations, the National Crime Squad provides the investigative capability at the tactical and operational levels for policing matters whilst the National Investigation Service (HM Customs and Excise) provides a similar capability in excise issues. Different agencies will have different parts to play in each operation depending on the lines of investigative attack to which any given criminal network will be vulnerable. 
Inadequate partnership working creates vulnerability in enforcement measures that organised crime can exploit. Williams identifies the essence of partnership working and consequences of it not working properly.

The battle against criminal and trafficking organisations is . . . a battle of unequals: it is a struggle between a government composed of multiple organisations and constituencies, with diverse objectives and interests, and an organisation with a single purpose or goalthe maximisation of profits. . . . Unfortunately, intelligence about drug trafficking and other transnational crime is often jealously guarded, bureaucratically compartmentalised and fragmented, and disseminated without any clear sense of purpose or direction. (Williams, 1998: 269)

Both within the UK and in other EU Member States it is the national interests that matter rather than those of individual enforcement agencies. Partnership in the pan-European fight against organised crime lends itself readily to UK cross-cutting, best value political initiatives.

\section{Prevention}

Crime prevention has evolved in recent years from a level at which older constables approaching retirement would spend their days dispensing target-hardening and personal safety advice to anyone who thought to ask for it, to the level of a science in which whole estates (residential, commercial or industrial) are 'secured by design' (www.homeoffice.gov.uk/crimprev/rbinit-4.htm) and comprehensive community safety strategies are required by law (Crime and Disorder Act 1998). Even so, it is difficult to equate strategies intended to reduce attacks on persons or premises with what might be needed to tackle the very different phenomenon of organised crime in which criminal groups and networks operate as multinational businesses (Fiorentini \& Peltzman, 1995).

There are a number of issues that can be addressed when considering strategies for preventing national and transnational serious and organised crime: ${ }^{6}$

- Cooperation between governments and enforcement agencies

- Strategic threat assessments

- Harmonisation of laws and operational practices

- Weaknesses of individual governments and enforcement agencies

- Strength of criminal networks

- State-organised criminality

The first two points are addressed through proactive investigation and formal instruments of cooperation and partnership as discussed above. 
To combat criminal organisations and networks that operate globally, enforcement agencies from different nations have to cooperate and work together. Different national jurisdictions have to be made to work in unison. No one nation, let alone a single enforcement agency within any given nation, can combat transnational organised crime singlehandedly. To cooperate effectively nations must have the internal structures to address transnational policing issues, and in the UK the NCIS, the National Crime Squad and the Scottish Crime Squad are best placed to respond to policing initiatives and directives from Europol.

Another aspect of cooperation between governments and enforcement agencies concerns strategic threat assessments: the means by which the nature of the threat posed by organised crime can be determined. Enforcement agencies provide operational intelligence for intelligence agencies such as the NCIS to analyse. Such analysis then informs the national contribution to the EU threat assessment (Bruggeman, 1998: 85).

Harmonisation of laws does not necessarily mean the writing of a single EU Criminal Code. It is about achieving common definitions, common standards and common methodologies between different national enforcement agencies (EU Action Plan, para. 6(b)). It could include "making it an offence under the laws of each Member State for a person, present in its territory, to participate in a criminal organisation, irrespective of the location in the Union where the organisation is concentrated or is carrying out its criminal activity' (Action Plan, para. 8(1)). But if this were not to be the case, then it is about ensuring that such a lacuna does not inhibit enforcement and judicial agencies. Achieving a consensus on what constitutes crime and how laws can be enforced ensures that there will be no national havens for criminals to seek refuge in (G8 Ministerial Communiqué on Combating Transnational Organised Crime, October 1999, para. 17; see also Williams 1998: 259 \& 263). This is not radical. It is merely an extension of the philosophies that underpin international extradition law (Shaw, 1997: 482). Indeed, arguably the harmonisation of domestic laws gives greater and more varied scope for investigation and prosecution than the establishment of a single EU criminal code and a single EU prosecutor. The establishment of Eurojust, a judicial sister-body to Europol, furthers this aim (Tampere Conclusions, para. 46). Such ideas are already being debated of course, but specifically in relation to fraud against the EU itself (House of Lords, 1999).

In 1994 the then UN Secretary-General Boutros Boutros-Ghali observed in a speech to the World Ministerial Conference on Organised Transnational Crime in Naples that:

One of the best ways of preventing transnational crime is to contribute to the development of countries experiencing economic difficulties and to introduce transparency in their political and social life. ${ }^{7}$ 
The fall of communism in Europe has been succeeded by a battle for control of the post-communist economies between the fledgling democracies and organised crime (Handelman, 1994). The history of corruption and the black market in communist states has provided fertile ground for criminal networks that seek to infiltrate or corrupt government officials and law enforcement agents. Only by strengthening individual governments and enforcement agencies will their vulnerability to such attack be reduced. The National Crime Squad plays its part in this aspect of organised crime prevention by promoting human rights, accountability and agency integrity through twinning schemes in which National Crime Squad personnel advise and train postcommunist enforcement agencies in investigative tactics and techniques and anticorruption issues. Applicant states seeking membership of the EU must reach accession criteria in law enforcement and judicial matters as part of the EU drive to prevent organised crime finding new avenues of access to criminal opportunities in the EU. ${ }^{8}$ Such twinning schemes aim to assist developing nations to achieve the desired standards.

The strength of any given criminal organisation or network is derived from a number of factors:

- Access to illicit and legal markets to generate profit

- Personnel with varying skills or access to public authorities

- Capability to counter enforcement agencies either through evasion or violence

- A context within which laws are weakly enforced

- Cooperation with other criminal groups

These factors are also, by definition, points of vulnerability at which to attack organised crime. Any one agency will have varying capability to impact on these different vulnerabilities. Illicit markets are generated within the context of government regulation. To cite one very straightforward example, drugs are smuggled because they are illegal. Whilst an investigative agency cannot determine government regulatory policy, investigations have the potential to generate intelligence about the manner in which criminal markets are shared between rival groups (Polo, 1995). This in turn could influence decision-making when drafting regulations to control activities and powers of enforcement. Similarly, intelligence generated from investigations, if properly analysed, can contribute to a better understanding of how profits from crime are then laundered through legitimate market places. Identifying the links between illicit profits and legal markets will provide a better means to regulate legal markets, thus reducing opportunities for laundering (for estimates of the scale of illicit economies see House of Commons, 1995: xii, xiii, xviii \& xix; see also Celentani et al., 1995). Investigation intelligence is analysed at different levels and for various purposes by both the NCIS and the National Crime Squad. 
Regulatory regimes and controlled access to legal markets can be circumvented through corrupt public officials. Various integrity measures can be taken to minimise the risk of placing individuals vulnerable to corruption in sensitive posts. Again, intelligence arising from investigations can and does highlight issues of corruption. It is at this level that local forces potentially have a role to play. Community safety strategies could be a vehicle by which issues of 'town hall' corruption can be addressed. Laundering funds through local construction projects or through betting shops are two of the options available to organised crime groups and local police force support for local authority regulation of such businesses can help reduce the vulnerability of such businesses to attacks by organised crime.

Rigorous enforcement of laws does prevent offending and can influence social attitudes. The significant reduction in Christmas drinkdriving arrests and convictions over the last decade demonstrates this point. The converse is also true. A policy of cautioning persons for personal possession of illicit drugs, or even of ignoring such an offence, can lead to the wider public perception that such criminal behaviour is, if not actually condoned, at least considered by the authorities not to present a significant threat to society. Such a perception misses the point that such apparently minor offences are the culmination of a chain of organised criminality focusing on production, importation and distribution networks sustained by crime and protected by violence. Where regulations and laws are not strictly enforced, then opportunities present themselves for organised crime groups either to engage in primary criminality, or to launder illicit profits, without challenge. Celentani et al. (1995) have interesting comments to make, within the context of pure economic theory, about optimal levels of regulation and tolerance within government authorities that allow organised crime to make some profit but not too much. Such a Faustian pact is unlikely ever to be politically acceptable in a corruption-free administration. The part that investigative agencies can play in contributing to this prevention strategy is obvious: detect criminals and lock them up. But by learning from each investigation, analysing and sharing the intelligence generated, the value of each individual operation goes beyond the detection and disruption of individual criminals and their immediate networks. The information so gleaned becomes a 'profit of enforcement' to re-invest in developing further prevention and investigative strategies.

Using investigations to divide and rule criminal groups prevents criminal cooperation. Cooperation within criminal groups, both vertically from 'god-father' to 'foot soldier' and horizontally between different groups, is vulnerable to attack by enforcement agencies through the use of informants, and by judicial bodies through sentences that recognise cooperation with law enforcement. The opportunism, competition and mistrust that exist within and between criminal networks are resources for enforcement agencies to exploit. Using tactics to 
exploit these resources enables agencies to disrupt criminality and so prevent and inhibit its effective operation.

The final element of organised crime for consideration with a view to prevention is state-organised criminality (Chambliss, 1989; see also Passa, 1993; Van Duyne, 1997). Whereas some states are vulnerable to the strength of organised crime networks, others may choose actively to cooperate with such networks (Williams, 1998: 268), perhaps as indirect and covert means of prosecuting a foreign policy initiative to disrupt or destabilise another state. Prevention at this level is largely the prerogative of government intervention. Nevertheless, it will be for enforcement agencies to work in partnership with governments to detect and disrupt, and so prevent, the criminal activities of statesponsored networks. Europe may well find itself under attack from criminal organisations based in, if not sponsored by, non-EU states seeking to exploit from afar criminal opportunities presented by the wealth of the EU and its budget. Bogus schemes set up within the EU to attract subsidy in which the profits are diverted to organisations in a non-EU state is but one example. The EU will look to its constituent states and their enforcement agencies to tackle such criminality.

\section{Conclusion}

The EU must rely on its Member States because it has no enforcement agency of its own. Europol and Eurojust are intended to improve and facilitate cooperation between Member States for the common good rather than assume enforcement responsibility through the EU. Issues of sovereignty are closely linked to law enforcement. And with more direction from Europe in the fight against organised crime come issues of accountability to individual governments and citizens (McLaughlin, 1992; Walker, 1993).

The European Court of Justice, presently, cannot intervene in the actions of Member State domestic enforcement agencies (TA, Article 35(5)). Nor would the current British Government, or many other EU states, wish it to be able to. Some aspects of proactive investigation and partnership working will remain intergovernmental but commentators have argued that moving treaty-based cooperative measures, such as Europol and the Schengen Information System, to the First Pillar of EU business would render these structures more accountable to judicial control (Hall, 1999), thereby instilling greater public confidence in these mechanisms and so a greater willingness to assist rather than resist these enforcement structures.

Structures for accountability are strong in the UK, particularly so for those agencies that are involved in the national fight against organised crime. The sorts of proactive techniques required to investigate higher echelon criminality are subject to rigorous authority regimes, including in some cases independent preview by judicial commissioners (Part III of the Police Act 1997). Further regulation and accountability for police actions is enshrined in the Regulation of 
Investigatory Powers Act. Again, in some cases prior authorisation by judicial commissioners is required before a tactic can be deployed. The Human Rights Act 1998 gives effect to the European Convention on Human Rights in UK courts. Police Authorities and, in the case of the NCIS and National Crime Squad, Service Authorities provide a structure for accountability to bodies that include elected councillors and independent citizens (s. 3 of the Police Act 1996; ss 1 and 47 of the Police Act 1997).

These safeguards ensure that, as an investigative agency, the National Crime Squad is well positioned to address the three aspects of policing organised crime that will increasingly be influenced by Europe in the years ahead: proactive investigations, partnership working and contributing to prevention strategies, all with the intention of combating the threat posed by organised crime.

\section{References}

Bruggeman, W. (1998) 'Transnational Crime: Recent Trends and Future Prospects' in Cullen, P. and Gilmore, W. (eds), Crime Sans Frontières: International and European Legal Approaches. Edinburgh: EUP, 85-92.

Fiorentini, G. and Peltzman, S. (1995) The Economics of Organised Crime. Cambridge: CUP.

Celentani, M., Marrelli, M. and Martina, R. (1995) 'Regulating the Organised Crime Sector' in Fiorentini, G. and Peltzman, S. (eds), The Economics of Organised Crime. Cambridge: CUP, 253-73.

Chambliss, W. (1989) 'State-Organised Crime' Criminology 27: 183

Gallagher, D. (1998) European Police Co-operation: Its Development and Impact Between 1967 and 1997 in an Anglo-French Trans-Frontier Setting. Unpublished $\mathrm{PhD}$ thesis, University of Southampton.

Hall, B. (1999) Policing Europe: EU Justice and Home Affairs Co-operation. London: Centre for European Reform.

Handelman, S. (1994) 'The Russian Mafiya' Foreign Affairs 73: 83.

Harfield, C. (1999) These Foreign Laws: Issues Facing Investigators in England and Wales When Gathering Evidence of Criminality from European Jurisdictions. Unpublished LLM thesis, University of Sussex.

Home Office (1999) Interception of Communications in the United Kingdom: A Consultation Paper. $\mathrm{Cm}$ 4368. Also available at http://www.homeoffice.gov.uk/oicd/ ioca.pdf.

House of Commons (1995) Organised Crime. Home Affairs Committee Report, HC Session 1994-95, 18-I.

House of Lords (1999) Prosecuting Fraud on the Communities' Finances-The Corpus Juris. Select Committee on European Communities, HL 62 Session 1998-99.

Knudsen, P. (1998) 'Fraud Against the EC Budget' in Cullen, P. and Gilmore, W. (eds), Crime Sans Frontières: International and European Legal Approaches. Edinburgh: EUP, 111-15.

McLaughlin, E. (1992) 'The Democratic Deficit: European Union and the Accountability of the British Police' British Journal of Criminology 32: 473.

Nilsson, H. (1998) 'Co-operation in Justice and Home Affairs' in Cullen, P. and Gilmore, W. (eds), Crime Sans Frontières: International and European Legal Approaches. Edinburgh: EUP, 116-23.

Passa, N. (1993) 'Structural Sources of International Crime: Policy Lessons from the BCCI Affair' Crime, Law and Social Change 20: 293.

Polo, M. (1995) 'Internal Cohesion and Competition Among Criminal Organisations' in Fiorentini, G. and Peltzman, S. (eds), The Economics of Organised Crime. Cambridge: CUP, $87-115$ 
Shaw, M. (1997) International Law, 4th edn. Cambridge: Grotius.

Van Duyne, P. (1997) 'Organised Crime, Corruption and Power' Crime, Law and Social Change 26: 201.

Walker, N. (1993) 'The Accountability of European Police Institutions' European Journal of Criminal Policy and Research 1: 32.

Williams, P. (1998) 'Transnational Criminal Organisations and International Security' in Klare, M. and Chandrani, Y. (eds), World Security: Challenges for a New Century, 3rd edn. New York: St Martin's Press.

Wrench, P. (1998) 'The G8 and Transnational Organised Crime' in Cullen, P. and Gilmore, W. (eds), Crime Sans Frontières: International and European Legal Approaches. Edinburgh: EUP, 39-43.

\section{End Notes}

1. The Action Plan to Combat Organised Crime, Council of Europe 7421/97, ch. 1, and Organised Crime, the Third Report of the Home Affairs Committee, HC Session 1994-95, 18-I, outline the issues and the scale of the threat to the EU as a whole and the UK in particular.

2. I am grateful to Dr Frank Gallagher not only for giving me a copy of this work but also for discussing many of the issues in depth with me as I conducted my own research.

3. Held on 15 and 16 October 1999. The text of the Conclusions (in English) is available at http://europa.eu.int/council/off/conclu/oct99/oct 99 en.htm.

4. For the UK position on Justice and Home Affairs within the EU visit the Foreign and Commonwealth website at http://193.114.50.10/news/keythemepage.asp?89 where the UK's commitment is outlined.

5. The Scottish Crime Squad is founded on the same basis as the former regional crime squads in England and Wales prior to the statutory creation of the National Crime Squad. It is thus not strictly equivalent in status to the National Crime Squad, being rather one of the agencies with which the National Crime Squad is expected to work under s. 48(3)(e) of the Police Act 1997. It remains to be seen how the new Drug Enforcement Agency in Scotland impacts on the work of the Scottish Crime Squad.

6. The National Crime Squad has a remit to prevent and detect serious crime which is of relevance to more than one police area in England and Wales' and to 'act in support of other law enforcement agencies in the prevention and detection of serious crime': Police Act 1997, ss 48(2) and 48(3)(e).

7. The full text of this speech is available at http://www.alternatives.com/crime/ ghali.html.

8. For the details of this see the Pre-Accession Pact on Organised Crime Between the Member States of the European Union and the Applicant Countries of Central and Eastern Europe and Cyprus (98/C 220/01), which was adopted in 1998 under Title VI of the Treaty on European Union (Maastricht, 1992). 